\title{
Potential Influence of Climate Change on the Acid-Sensitivity of High-Elevation Lakes in the Georgia Basin, British Columbia
}

\author{
Donna Strang and Julian Aherne \\ Environmental and Life Sciences, Trent University, 1600 West Bank Drive, Peterborough, ON, Canada K9J 7B8 \\ Correspondence should be addressed to Julian Aherne; jaherne@trentu.ca
}

Received 28 October 2014; Revised 23 February 2015; Accepted 24 February 2015

Academic Editor: Harry D. Kambezidis

Copyright (C) 2015 D. Strang and J. Aherne. This is an open access article distributed under the Creative Commons Attribution License, which permits unrestricted use, distribution, and reproduction in any medium, provided the original work is properly cited.

\begin{abstract}
Global climate models predict increased temperature and precipitation in the Georgia Basin, British Colmbia; however, little is known about the impacts on high-elevation regions. In the current study, fifty-four high-elevation lakes (754-2005 m a.s.l.) were studied to investigate the potential influence of climate change on surface water acid-sensitivity. Redundancy analysis indicated that the concentration of nitrate, dissolved organic carbon, and associated metals was significantly influenced by climate parameters. Furthermore, these components differed significantly between biogeoclimatic zones. Modelled soil base cation weathering for a subset of the study lakes $(n=11)$ was predicted to increase by $9 \%$ per $1^{\circ} \mathrm{C}$ increase in temperature. Changes in temperature and precipitation may potentially decrease the $\mathrm{pH}$ of surface waters owing to changes in anthropogenic deposition and organic acid production. In contrast, increased soil base cation weathering may increase the critical load (of acidity) of high-elevation lakes. Ultimately, the determining factor will be whether enhanced base cation weathering is sufficient to buffer changes in natural and anthropogenic acidity. Mountain and high-elevation regions are considered early warning systems to climate change; as such, future monitoring is imperative to assess the potential ramifications of climate change on the hydrochemistry and acid-sensitivity of these surface waters.
\end{abstract}

\section{Introduction}

It is widely accepted that changes in climate may significantly alter the biological, physical, and chemical systems of mountainous regions [1-3]. Their potentially dramatic response has been attributed to the pronounced rise in temperature (1.5$2.0^{\circ} \mathrm{C}$ during 1980 to 1995$)$ in high-elevation regions compared with the global average $\left(0.5^{\circ} \mathrm{C} ;[4]\right)$ and to the influence of changes in glacier, ice, and snow cover [5]. Accordingly, mountain and high-elevation regions are considered as early warning systems, providing valuable insight into the potential hydrological and ecological responses owing to climate [1].

A range of potential impacts on the hydrogeochemistry of high-elevation and alpine aquatic ecosystems have been reported. It has been suggested that altered hydrological flushing rates and residence times, and increased inputs of nutrients and other solutes may cause the acidification of surface waters $[6,7]$. Soil mineral weathering rates $[8]$ and the amount and duration of snowpack are also expected to vary [9]. Experimental climate change treatments in regions of the Rocky Mountains, USA, have shown that changes in snow pack cover significantly influence the mineralization rate of both nitrogen $(\mathrm{N})$ and carbon [10]. These changes in nutrient hydrogeochemistry have been associated with altered plant community competition, species dominance, and their geographical range [11].

The Georgia Basin, located in southwestern British Columbia, Canada, is dominated by four mountain ranges. Few studies have focused on the high-elevation lakes and catchments that scatter this region. One recent study [12], however, indicated that these lakes $(n=72)$ are sensitive to acidification and that $18 \%$ currently receive sulphur (S) deposition in excess of their critical load of acidification (CL(A)). The study also suggested that precipitation and the cover of glacier and ice significantly influenced the $\mathrm{pH}$ and acid neutralizing capacity (ANC) of these lakes. Temperature 
and precipitation are predicted to increase in the Georgia Basin $[13,14]$; it is uncertain how the hydrogeochemistry of these catchments will respond.

Although it is difficult to predict the impacts of climate change on the hydrogeochemistry of high-elevation and alpine ecosystems, an attempt to understand the potential implications of changes in temperature and precipitation may aid in the protection (or rehabilitation) of these systems. The objective of this study, therefore, was to evaluate which chemical components of these ecosystems are significantly influenced by temperature and precipitation and how climate change may influence the acid-sensitivity of these highelevation catchments. Potential changes in lake chemistry, according to biogeoclimatic zone, were assessed based on a recent survey of high-elevation lakes [12]. In addition, weathering rates under increased temperature were estimated for a subset of catchments using the PROFILE model [15].

\section{Methods}

2.1. Study Area. The Georgia Basin encompasses $48000 \mathrm{~km}^{2}$ and is surrounded by four mountain ranges: the Olympic Mountains, Vancouver Island Ranges, the Coast Ranges, and the Cascades. The area receives high levels of precipitation especially along the coastal regions as a result of orographic precipitation. Modelled precipitation amounts (Parameter Elevation Regressions on Independent Slopes Model (PRISM) [16]) range from 400 to almost $5000 \mathrm{~mm} \mathrm{yr}^{-1}$ for the 30-year climate normals (1961-1990). The basin encompasses seven biogeoclimatic zones (regions characterized as having specific climate, soil, and vegetation communities): Coast Douglas Fir (CDF), Coastal Western Hemlock $(\mathrm{CWH})$, Mountain Hemlock (MH), Interior Douglas Fir, Engelmann Spruce-subalpine Fir, and Coastal and Interior Mountain-heather Alpine (AT) zones ([17]; Figure 1). Air temperature within these zones varies greatly, with mean annual temperatures (MAT) ranging from $10.5^{\circ} \mathrm{C}$ in the low elevation $\mathrm{CDF}$ zone to $-4.0^{\circ} \mathrm{C}$ in the high altitude $\mathrm{AT}$ zone [17].

During October 2008, 72 lakes were sampled within the Georgia Basin and 54 were classified as high-elevation $(>750 \mathrm{~m}$ ) lakes (Figure 1). The lakes were chosen based on lithology, the majority of the lake catchments being dominated by the rock types of granodiorite and quartz diorite, both characterized by low buffering capacity and low mineral weathering rates. The elevation of the study lakes ranged between 754 and $2005 \mathrm{~m}$ a.s.l. with $72 \%$ of the lakes $\geq$ $1000 \mathrm{~m}$ a.s.l. The lakes were characterised by low conductivity (median $=6.0 \mu \mathrm{Scm}^{-1}$ at $25^{\circ} \mathrm{C}$ ) and low base cation and nutrient concentrations (Table 1), typical of the dilute nature of high-elevation lakes. Twenty percent of the study lakes had $\mathrm{pH}<6$ and $24 \%$ had ANC (estimated as the difference between the sum of base cations and the sum of acid anions in $\mu \mathrm{eq} \mathrm{L} \mathrm{L}^{-1}$ ) below $20.0 \mu \mathrm{eq} \mathrm{L} \mathrm{L}^{-1}$ (Table 1). The lakes were classified as sensitive to acidic atmospheric deposition [12] and for many of the same reasons are considered to be sensitive to climate change.
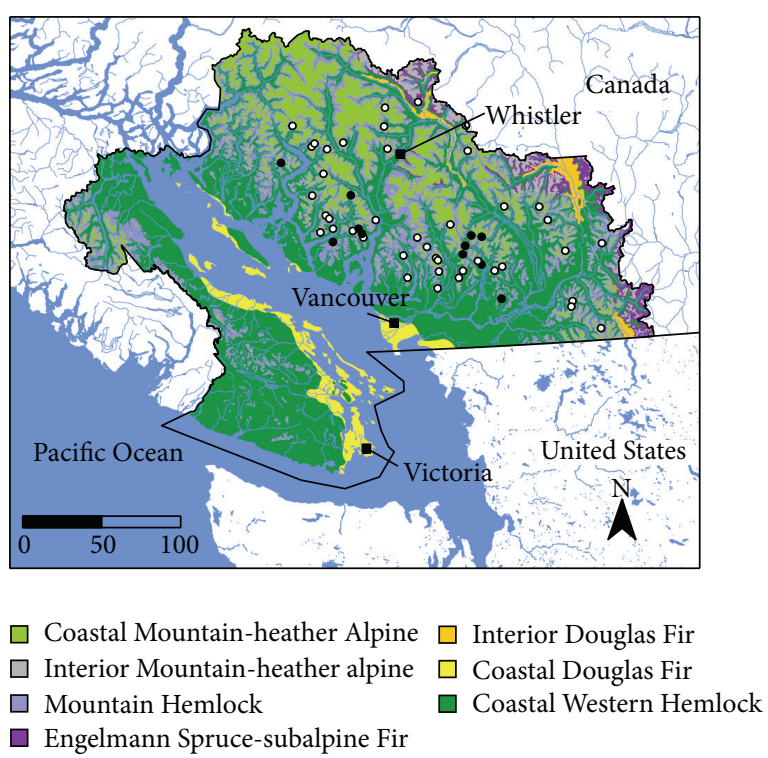

FIgure 1: Location of the Georgia Basin, British Columbia, Canada (delineated by bold black line). The study lakes $(n=54)$ are denoted by circles while major cities are denoted by filled squares. Filled circles are indicative of sites where both water and soil samples were collected $(n=11)$. The major biogeoclimatic zones within the Georgia Basin are also shown.

\subsection{Field Sampling and Laboratory Analysis}

2.2.1. Water Sampling. Water samples were collected centrelake from a float-equipped Bell 206 helicopter in October 2008. Positions were logged using a Garmin 76S global positioning unit. Surface water conductivity, $\mathrm{pH}$, and temperature were measured in situ using a Yellow Springs Instrument Model 6600 sonde. Near-surface water samples were collected in precleaned plastic bottles and kept cool during shipment to laboratories (within approximately 24 hours). Water samples were analyzed for $\mathrm{pH}$, major anions and cations, dissolved organic carbon (DOC), and metals. A summary of methods used for all water chemistry analysis and quality assurance/quality control procedures is given by Strang et al. [12].

2.2.2. Soil Sampling. Soil samples were collected at two depths $(0-15 \mathrm{~cm}$ and $15-30 \mathrm{~cm})$ from a subset of the lake sites $(n=11)$ between 2006 and 2008 using a soil auger; at each lake catchment three distal plots were established and composite soil samples were collected by auger from four points by depth. Soil bulk density and volumetric moisture content were measured by soil core following de Vos et al. [21] Soil samples were air-dried, sieved to $<2 \mathrm{~mm}$, and analysed for particle size (sand, silt, and clay) using a Horiba Partica LA-950; soil surface area was calculated from particle size following Warfvinge and Sverdrup [15]. Soil organic matter content was estimated as loss on ignition (LOI), which was determined by igniting samples in a muffle furnace at $450^{\circ} \mathrm{C}$ for 8 hours. Quantitative mineralogy was determined for site composited soil samples $(n=11$, composite of plot and 
TABLE 1: Selected chemical characteristics of study lakes $(n=54)$ in the Georgia Basin, British Columbia, sampled during October 2008 (P25 refers to the 25th percentile while P75 refers to the 75th percentile; ANC = acid neutralizing capacity and DOC $=$ dissolved organic carbon).

\begin{tabular}{|c|c|c|c|c|c|c|}
\hline Variable & Mean & Min. & P25 & Median & P75 & $\operatorname{Max}$ \\
\hline Conductivity $\left(\mu \mathrm{S} \mathrm{cm}^{-1}\right.$ at $\left.25^{\circ} \mathrm{C}\right)$ & 6.50 & 2.00 & 4.00 & 6.00 & 8.00 & 18.0 \\
\hline $\operatorname{ANC}\left(\mu \mathrm{eq} \mathrm{L}{ }^{-1}\right)$ & 47.7 & 10.6 & 20.9 & 41.5 & 72.0 & 159 \\
\hline $\mathrm{NO}_{3}^{-}\left(\mu \mathrm{eq} \mathrm{L}^{-1}\right)$ & 1.82 & 0.01 & 0.29 & 0.87 & 2.44 & 8.64 \\
\hline $\mathrm{SO}_{4}{ }^{2-}\left(\mu \mathrm{eq} \mathrm{L}{ }^{-1}\right)$ & 8.86 & 0.44 & 5.21 & 7.91 & 10.2 & 42.5 \\
\hline $\mathrm{Ca}^{2+}\left(\mu \mathrm{eq} \mathrm{L}{ }^{-1}\right)$ & 39.5 & 8.08 & 19.7 & 35.2 & 55.9 & 119 \\
\hline $\mathrm{Na}^{+}\left(\mu \mathrm{eq} \mathrm{L} \mathrm{L}^{-1}\right)$ & 13.7 & 4.92 & 9.98 & 13.5 & 17.1 & 27.4 \\
\hline $\mathrm{Mg}^{2+}\left(\mu \mathrm{eq} \mathrm{L}^{-1}\right)$ & 6.64 & 1.32 & 3.21 & 5.06 & 9.22 & 29.8 \\
\hline $\mathrm{K}^{+}\left(\mu \mathrm{eq} \mathrm{L}^{-1}\right)$ & 3.15 & 1.07 & 1.69 & 2.36 & 3.56 & 14.0 \\
\hline $\operatorname{DOC}\left(\mathrm{mg} \mathrm{L}^{-1}\right)$ & 1.15 & 0.00 & 0.46 & 0.74 & 1.54 & 7.22 \\
\hline $\mathrm{pH}$ & 6.34 & 5.44 & 6.12 & 6.22 & 6.70 & 7.12 \\
\hline $\mathrm{Al}\left(\mu \mathrm{g} \mathrm{L}^{-1}\right)$ & 59.9 & 8.00 & 20.7 & 35.8 & 77.0 & 337 \\
\hline $\mathrm{Pb}\left(\mu \mathrm{g} \mathrm{L}^{-1}\right)$ & 0.05 & 0.00 & 0.02 & 0.03 & 0.06 & 0.66 \\
\hline
\end{tabular}

depth samples) by X-ray powder diffraction using a Siemens (Bruker) D5000 Bragg-Brentano diffractometer under the Rietveld method [22]. The percentage of plagioclase (determined by X-ray diffraction) consisting of albite and anorthite was set at $65 \%$ and $35 \%$, respectively, based on previous studies in the Georgia Basin [23]. Weathering rate for each study site $(n=1)$ was calculated using the PROFILE (version 5.1) steady-state soil chemistry model, which is driven by soil mineralogy, bulk density, mineral surface area, and moisture content [15]. PROFILE has been widely used in Europe and North America to estimate weathering rates [24-26]. Model application and data inputs followed Aherne et al. [27] and Mongeon et al. [28].

2.3. Catchment Data. Catchment boundaries for the study sites were delineated from a digital elevation model (DEM: 1:20 000, BC Ministry of Environment) using a geographic information system (GIS). Land cover data for each catchment were delineated from the 1:250 000 Baseline Thematic Mapping (version 2, BC Ministry of Environment), which was compiled from Landsat 7 imagery. Catchment lithology was obtained from the digital geology map of BC (1:250 000, BC Ministry of Energy, Mines and Petroleum Resources). Long-term mean annual precipitation (MAP) and MAT data were estimated by PRISM at a $4 \mathrm{~km}$ by $4 \mathrm{~km}$ grid resolution [16]. The biogeoclimatic zone of each study site was assigned using a digital map of biogeoclimatic zones for the region (1:20 000; BC Forest Service Forest Science Program). Future climate forecasts (i.e., temperature and precipitation) were taken from the CGCM2 model developed by the Canadian Centre for Climate Modelling and Analysis [19] under the Intergovernmental Panel on Climate Change (IPCC) A2 scenario (continued population and temperature rise, increasing atmospheric $\mathrm{CO}_{2}$ concentrations [20]). Climate forecasts were downscaled ( $400 \mathrm{~m}$ by $400 \mathrm{~m}$ resolution) to each study lake using the ClimateBC model and obtained from Wang et al. [18]. Annual average total (wet and dry) anthropogenic $\mathrm{S}$ and $\mathrm{N}$ deposition for the period 2005-2006 was obtained from the Community Multiscale Air Quality (CMAQ [29]) model at a $4 \mathrm{~km}$ by $4 \mathrm{~km}$ grid resolution.
2.4. Data Management and Statistical Analysis. Lake chemical variables with observations < detection limit (DL) and deemed pertinent to the objective of the study (i.e., nitrate $\left(\mathrm{NO}_{3}{ }^{-}\right)$and $\left.\mathrm{DOC}\right)$ were assigned random values between 0 and the analytical DL for the variable, following standard data imputation techniques.

All statistical analyses were conducted using STATISTICA 7.0 and XLStat software; alpha values were set at 0.05. Redundancy analysis (RDA) was used to evaluate which lake chemical variables were significantly influenced by temperature and precipitation. Redundancy analysis is a multivariate technique similar to principal component analysis but explains the variance of the dependent variables by a linear combination of predictor variables [30], and it has been widely used in hydrogeochemical studies (e.g., [3133]). Variables that were not normally distributed were logtransformed to ensure normality; however, parameters that remained non-normal (primarily land cover and geology characteristics) were retained in the analysis due to the robustness of the RDA statistic and the importance of these parameters to lake water chemistry. Differences in lake chemistry between biogeoclimatic zones were evaluated to explore how the hydrogeochemistry of high-elevation aquatic ecosystems might respond to climate change, as these zones are characterized by different temperature and precipitation regimes ([17]; Table 2). The nonparametric Kruskal-Wallis test was used to determine which chemical variables differed significantly between biogeoclimatic zones; only variables found to be significantly different were reported in detail.

\section{Results and Discussion}

3.1. Climate Change in the Georgia Basin. The CGCM2 model predicted that both air temperature and precipitation will increase in the Georgia Basin under the IPCC A2 scenario; the average increase in mean temperature from present day at the study catchments was $1.1,2.1$, and $3.4^{\circ} \mathrm{C}$ for the years 2020, 2050 (Figure 2, [18]) and 2080, respectively. Increases in precipitation were predicted at 82,143 , and $239 \mathrm{~mm}(2.4$, 4.2, and 7.0\%) for 2020, 2050 (Figure 2, [18]) and 2080, 
TABLE 2: Elevation, climate, vegetation, and soil characteristics of the Coastal Western Hemlock (CWH), Mountain Hemlock (MH), and Mountain-heather Alpine (AT) biogeoclimatic zones in the Georgia Basin, British Columbia [17]. (MAT = mean annual temperature, MAP = mean annual precipitation, and $\mathrm{MMT}=$ mean monthly temperature).

\begin{tabular}{|c|c|c|c|c|}
\hline $\begin{array}{l}\text { Biogeoclimatic } \\
\text { zone }\end{array}$ & Elevation $(\mathrm{m})$ & Climate & Dominant vegetation communities & Soil regime \\
\hline CWH & $900-1050$ & $\begin{array}{c}\mathrm{MAT}=8^{\circ} \mathrm{C} \\
\mathrm{MAP}=1000-4400 \mathrm{~mm} \\
\mathrm{MMT}>10^{\circ} \mathrm{C} \text { for } 4-6 \text { months }\end{array}$ & $\begin{array}{l}\text { Western hemlock (Tsuga heterophylla), } \\
\text { amabilis fir (Abies amabilis), yellow cedar } \\
\text { (Callitropsis nootkatensis) }\end{array}$ & $\begin{array}{l}\text { Humoferric } \\
\text { podzols, } \\
\text { ferrohumic } \\
\text { podzols } \\
\end{array}$ \\
\hline $\mathrm{MH}$ & $900-1800$ & $\begin{array}{c}\mathrm{MAT}=0-5^{\circ} \mathrm{C} \\
\mathrm{MAP}=1700-5000 \mathrm{~mm} \\
\mathrm{MMT}<0^{\circ} \mathrm{C} \text { for } 1-5 \text { months and } \\
>10^{\circ} \mathrm{C} \text { for } 1-3 \text { months }\end{array}$ & $\begin{array}{l}\text { Mountain hemlock (Tsuga mertensiana), } \\
\text { amabilis fir (Abies amabilis), yellow cedar } \\
\text { (Callitropsis nootkatensis) }\end{array}$ & Podzols, folisols \\
\hline AT & $>1650$ & $\begin{array}{c}\mathrm{MAT}=-4-0^{\circ} \mathrm{C} \\
\mathrm{MAP}=700-3000 \mathrm{~mm} \\
\mathrm{MMT}<0^{\circ} \mathrm{C} \text { for } 7-11 \text { months }\end{array}$ & Primarily treeless & $\begin{array}{l}\text { Orthic Regosols, } \\
\text { Humic Regosols }\end{array}$ \\
\hline
\end{tabular}

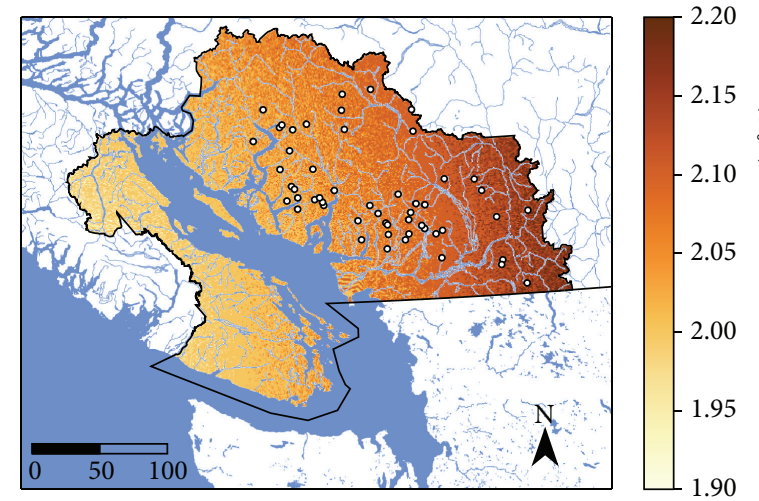

(a)

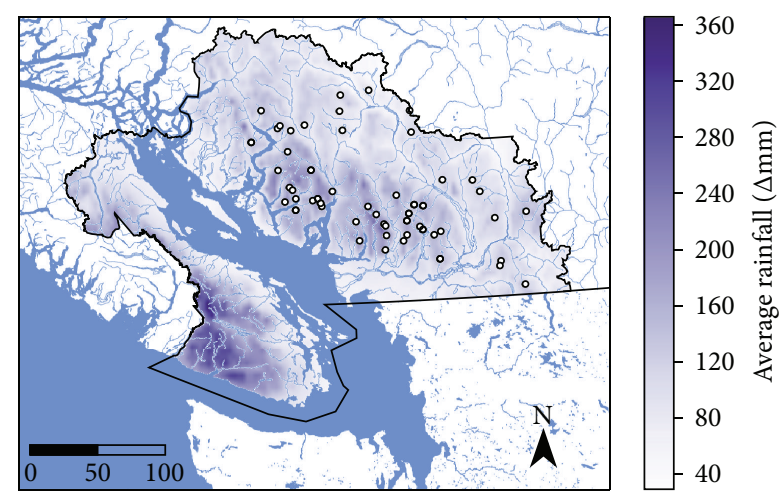

(b)

Figure 2: Predicted average temperature (a) and precipitation (b) delta increase for the Georgia Basin, British Columbia, between present day and 2050 [18]. Predictions based on model outputs from the CGCM2 model [19] under the IPCC A2 scenario [20]. The study lakes $(n=54)$ are depicted as white open circles.

respectively. Although general circulation models provide valuable insight into future climate scenarios, precision in estimating temperature and precipitation is limited owing to the complex topography of mountainous regions [1]. Furthermore, most meteorological stations in the Georgia Basin are located close to sea level; therefore estimates may be biased towards lower elevation regions [34]. The CGCM2 projections, however, were in good agreement with those released by the IPCC in their Fourth Assessment Report [35].

\subsection{Climate Change and Its Influence on Lake Water Chem-} istry. Changes in temperature and precipitation regimes in the Georgia Basin will undoubtedly influence the chemical composition of high-elevation lakes and the biogeochemical processes governing solute input and output within catchments. Therefore it is important to evaluate which chemical components of freshwater ecosystems are heavily influenced by temperature and precipitation. Redundancy analysis indicated that several chemical variables were significantly influenced by temperature and precipitation; two axes accounted for over $86 \%$ of the variance in the water chemistry data (Figure 3). The first axis (accounting for $>62 \%$ of the variance) was dominated by climate related variables (i.e., air temperature (0.828) and precipitation (0.422)). Modelled sulphur deposition was also heavily weighted on the first axis (0.718) accounting for anthropogenic influences (Figure 3); however, because of its strong relationship with precipitation and air temperature it was classified as a climate parameter. Deposition is highly influenced by precipitation [36, 37], with greater deposition found in areas with large amounts of precipitation owing to elevated "wash-out" or the "seeder-feeder" effect in mountainous regions $[6,38,39]$. Similarly, higher temperatures influence the conversion of $\mathrm{SO}_{2}$ to $\mathrm{SO}_{4}{ }^{2-}$, thereby increasing the concentration in wet deposition [36]. The second axis, accounting for approximately $24 \%$ of the variance, represented differences in land cover (e.g., forested area $(0.469)$ and alpine area $(-0.484))$.

Lake chemical parameters that were primarily related to climate characteristics were $\mathrm{NO}_{3}{ }^{-}(0.995)$, DOC (0.882), potassium $\left(\mathrm{K}^{+}:-0.637\right), \mathrm{pH}(-0.967)$, antimony (Sb: 0.731), cobalt (Co: 0.854$)$, copper ( $\mathrm{Cu}: 0.442)$, and lead ( $\mathrm{Pb}: 1.188$; Figure 3 ). Parameters that were primarily related to land 


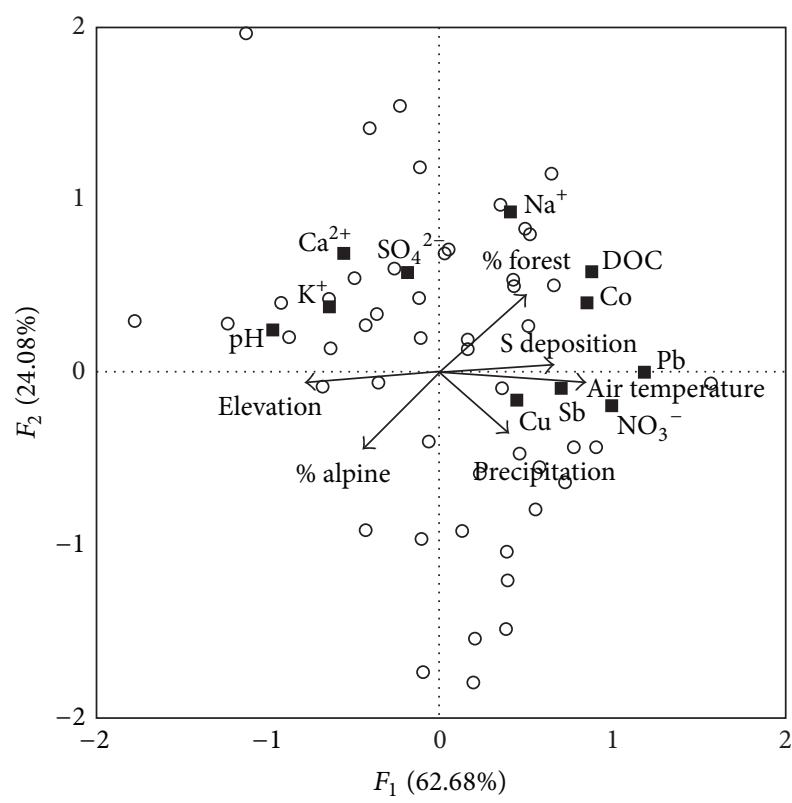

FIGURE 3: Redundancy analysis biplot for water chemical parameters in study lakes in the Georgia Basin, British Columbia. Black solid lines represent the explanatory variables (elevation, precipitation, air temperature, $\mathrm{S}$ deposition = sulphur deposition, $\%$ alpine $=\%$ alpine land cover, and $\%$ forest $=\%$ forested land cover) and black solid squares represent the water chemistry variables. (Note: several water chemistry variables were grouped together in the biplot to improve visual presentation: $\mathrm{Cu}=$ copper, $\mathrm{NO}_{3}{ }^{-}=$nitrate, $\mathrm{Sb}=$ antimony, $\mathrm{Pb}=$ lead, $\mathrm{Co}=$ cobalt, surface water temperature, $\mathrm{DOC}$ $=$ dissolved organic carbon, aluminum, manganese, $\mathrm{Na}^{+}=$sodium, silicon, $\mathrm{Ca}^{2+}=$ calcium, conductivity, magnesium, acid-neutralizing capacity, strontium, $\mathrm{SO}_{4}{ }^{2-}=$ sulphate, vanadium, barium, alkalinity, $\mathrm{pH}=\mathrm{pH}$, field $\mathrm{pH}, \mathrm{K}^{+}=$potassium, phosphorus, and uranium.) Open circles represent the study lakes.

cover characteristics were sulphate $\left(\mathrm{SO}_{4}{ }^{2-}: 0.588\right)$, calcium $\left(\mathrm{Ca}^{2+}: 0.690\right)$, and sodium $\left(\mathrm{Na}^{+}: 0.935\right.$; Figure 3). It is important to note, however, that the two land cover types (alpine and forested), although treated separately from climate parameters, are significantly influenced by differences in temperature and precipitation. In general, low temperature (higher elevation) catchments are dominated by alpine land cover whereas catchments with higher temperatures have a greater proportion of forested land cover.

Biogeoclimatic zones within mountains are characterized by different vegetation, MAT, MAP, and soil properties ([17]; Table 2); climate change is predicted to alter the range and size of these zones [40-42] and influence the chemistry of high-elevation lakes. The 54 study catchments were located across three biogeoclimatic zones: $\mathrm{MH}, \mathrm{CWH}$, and AT (Figure 1). Many of the chemical parameters that were strongly influenced by temperature and precipitation were also found to be significantly different between these three zones. The Kruskal-Wallis test indicated that $\mathrm{NO}_{3}{ }^{-}, \mathrm{DOC}, \mathrm{pH}, \mathrm{Co}$, $\mathrm{Cu}$, and $\mathrm{Pb}$ lake concentrations were significantly different between zones (Table 3 ).
TABLE 3: Mean values of the chemical characteristics of study lakes in each of the AT $(n=18)$, CWH $(n=16)$, and MH $(n=20)$ biogeoclimatic zones. Chemical parameters that differ significantly are indicated by bold lettering. Where differences lie is indicated by superscripts "a," "b," and "c" (e.g., elevation: the AT zone is significantly different than both the $\mathrm{CWH}$ and the $\mathrm{MH}$ zone; the $\mathrm{CWH}$ zone is significantly different than the $\mathrm{MH}$ zone).

\begin{tabular}{|c|c|c|c|}
\hline \multirow{2}{*}{ Variable } & \multicolumn{3}{|c|}{ Biogeoclimatic zone } \\
\hline & CWH & $\mathrm{MH}$ & AT \\
\hline ANC $\left(\mu\right.$ eq L $\left.{ }^{-1}\right)$ & 40.9 & 54.2 & 46.3 \\
\hline $\mathrm{NO}_{3}^{-}\left(\mu \mathrm{eq} \mathrm{L}^{-1}\right)$ & $3.77^{\mathrm{a}}$ & $1.23^{\mathrm{b}}$ & $0.68^{\mathrm{b}}$ \\
\hline $\mathrm{SO}_{4}{ }^{2-}\left(\mu \mathrm{eqL} \mathrm{L}^{-1}\right)$ & 7.88 & 9.01 & 9.87 \\
\hline $\mathrm{Ca}^{2+}\left(\mu \mathrm{eq} \mathrm{L}^{-1}\right)$ & 34.8 & 43.6 & 38.9 \\
\hline $\operatorname{DOC}\left(\mathrm{mg} \mathrm{L}^{-1}\right)$ & $2.00^{\mathrm{b}}$ & $1.17^{\mathrm{b}}$ & $0.39^{\mathrm{a}}$ \\
\hline $\mathrm{Mg}^{2+}\left(\mu \mathrm{eqL} \mathrm{L}^{-1}\right)$ & 6.12 & 7.34 & 6.31 \\
\hline $\mathrm{K}^{+}\left(\mu \mathrm{eq} \mathrm{L} \mathrm{L}^{-1}\right)$ & 2.31 & 3.44 & 3.57 \\
\hline $\mathrm{Na}^{+}\left(\mu \mathrm{eq} \mathrm{L}^{-1}\right)$ & $15.9^{\mathrm{b}}$ & $15.0^{\mathrm{b}}$ & $10.2^{\mathrm{a}}$ \\
\hline $\mathrm{pH}$ & $6.07^{\mathrm{a}}$ & $6.45^{\mathrm{b}}$ & $6.46^{\mathrm{b}}$ \\
\hline $\operatorname{Si}\left(\mu \mathrm{g} \mathrm{L}^{-1}\right)$ & $827^{\mathrm{b}}$ & $813^{\mathrm{b}}$ & $560^{\mathrm{a}}$ \\
\hline $\mathrm{Al}\left(\mu \mathrm{g} \mathrm{L}^{-1}\right)$ & $110^{\mathrm{b}}$ & $53.4^{\mathrm{b}}$ & $21.8^{\mathrm{a}}$ \\
\hline $\mathrm{Sb}\left(\mu \mathrm{g} \mathrm{L}^{-1}\right)$ & 0.03 & 0.02 & 0.02 \\
\hline $\operatorname{Co}\left(\mu \mathrm{g} \mathrm{L}^{-1}\right)$ & $0.04^{\mathrm{a}}$ & $0.02^{\mathrm{b}}$ & $0.01^{\mathrm{b}}$ \\
\hline $\mathrm{Cu}\left(\mu \mathrm{g} \mathrm{L}^{-1}\right)$ & $0.27^{\mathrm{a}}$ & $0.18^{\mathrm{b}}$ & 0.20 \\
\hline $\operatorname{Mn}\left(\mu \mathrm{gL}^{-1}\right)$ & $2.57^{\mathrm{b}}$ & 1.62 & $1.10^{\mathrm{a}}$ \\
\hline $\mathrm{Pb}\left(\mu \mathrm{g} \mathrm{L}^{-1}\right)$ & $0.11^{\mathrm{b}}$ & $0.04^{\mathrm{b}}$ & $0.02^{\mathrm{a}}$ \\
\hline Mean annual air temperature $\left({ }^{\circ} \mathrm{C}\right)$ & $6.36^{\mathrm{b}}$ & $4.37^{\mathrm{c}}$ & $2.87^{\mathrm{a}}$ \\
\hline Elevation (m) & $887^{\mathrm{b}}$ & $1242^{\mathrm{c}}$ & $1514^{\mathrm{a}}$ \\
\hline Nitrogen deposition $\left(\mathrm{kg} \mathrm{ha}^{-1} \mathrm{yr}^{-1}\right)$ & $10.4^{\mathrm{b}}$ & 8.48 & $5.80^{\mathrm{a}}$ \\
\hline Sulphur deposition $\left(\mathrm{kg} \mathrm{ha}^{-1} \mathrm{yr}^{-1}\right)$ & $5.38^{\mathrm{a}}$ & $3.61^{\mathrm{b}}$ & $2.72^{\mathrm{b}}$ \\
\hline Precipitation $\left(\mathrm{mm} \mathrm{yr}^{-1}\right)$ & 3617 & 3488 & 3218 \\
\hline$\%$ Forested & $56.4^{\mathrm{b}}$ & $39.3^{\mathrm{b}}$ & $0.72^{\mathrm{a}}$ \\
\hline$\%$ Ice and glacier & $0.35^{\mathrm{b}}$ & $0.69^{\mathrm{b}}$ & $6.87^{\mathrm{a}}$ \\
\hline \% Alpine & $23.1^{\mathrm{b}}$ & $35.4^{\mathrm{b}}$ & $73.8^{\mathrm{a}}$ \\
\hline
\end{tabular}

The relationship between DOC and temperature has been reported in many studies $[43,44]$; DOC decreased significantly from the CWH biogeoclimatic zone $\left(2.00 \mathrm{mg} \mathrm{L}^{-1}\right)$ through the $\mathrm{MH}$ zone $\left(1.17 \mathrm{mg} \mathrm{L}^{-1}\right)$ with its lowest concentrations found in the AT zone $\left(0.39 \mathrm{mg} \mathrm{L}^{-1} ; \mathrm{H}_{2,54}=27.53\right.$, $P<0.05$; Table 3). Along with temperature, the RDA analysis indicated that DOC concentrations were significantly weighted on the amount of forested land cover within the lake catchment (0.589; Figure 3). Most of the DOC in lakes is derived from surrounding soils or wetlands [45]. Accordingly, lakes draining catchments primarily dominated by thin soils or bare rocks typically have low DOC concentrations $[46,47]$. The percent of forested land cover between the biogeoclimatic zones differed significantly and decreased from the CWH zone (56.4\%) through the $\mathrm{MH}$ zone (39.3\%) with lowest values located in the AT zone $\left(0.72 \% ; \mathrm{H}_{2,54}=\right.$ 36.24, $P<0.05$; Table 3).

Lakes in the AT biogeoclimatic zone will potentially have the most significant change in DOC concentrations as a result of climate change. Krannitz and Kesting [41] predicted that tree lines will migrate upwards into the AT zone under 
future climatic conditions; some researchers have suggested that a $1^{\circ} \mathrm{C}$ increase in temperature will result in a $150-200 \mathrm{~m}$ elevational increase in forested land [48]. This encroachment into the AT zone may result in elevated DOC concentrations as a result of increased nutrient cycling [9], terrestrial productivity, and leaf litter production $[49,50]$. Increased DOC in surface waters could lead to shifts in biological species composition [51] due to changes in nutrient and light regimes [46]. Changes in the DOC concentrations of the CWH and $\mathrm{MH}$ biogeoclimatic zones may also be observed under increased warming due to projected increased terrestrial productivity in the $\mathrm{MH}$ zone [52] and decreased wetland area in the CWH zone [53].

Climate change induced fluctuations in DOC can alter metal concentrations in surface waters as many metals are transported to surface waters through complexation processes with DOC [46]. In particular, metals such as manganese $(\mathrm{Mn})$, aluminium $(\mathrm{Al}), \mathrm{Pb}, \mathrm{Cu}$, and $\mathrm{Co}$ are highly associated with DOC $[54,55]$. Metal concentrations in the surface waters of high-elevation lakes in the Georgia Basin are quite low ([12]; Table 1); nonetheless, metals in the 54 study lakes follow the same pattern of DOC. Lakes located in the AT biogeoclimatic zone had lower levels of metals compared with the $\mathrm{MH}$ and $\mathrm{CWH}$ zones (Table 3). Specifically, significant differences $(P<0.05)$ in $\mathrm{Al}\left(\mathrm{H}_{2,54}=23.39\right)$, $\mathrm{Co}\left(\mathrm{H}_{2,54}=21.32\right)$, $\mathrm{Cu}\left(\mathrm{H}_{2,54}=6.92\right), \mathrm{Mn}\left(\mathrm{H}_{2,54}=11.71\right)$, and $\mathrm{Pb}\left(\mathrm{H}_{2,54}=18.49\right)$ were observed. Under higher precipitation and temperature regimes, the toxicity of metals to aquatic organisms could be enhanced [56]. The AT biogeoclimatic zone may also experience increased DOC and metal concentrations owing to the significantly higher proportion of ice and glacier cover within the AT zone (6.87\%), compared to the CWH $(0.35 \%)$ and $\mathrm{MH}(0.69 \%)$ zones $\left(\mathrm{H}_{2,54}=16.91, P<0.05\right.$; Table 3$)$. Increased runoff from the melting of alpine glaciers [7] has been reported in high-elevation lakes in the European Alps [57] and increased runoff may further dilute lakes. Recent estimates suggest that, with increased temperature, glaciers in BC may disappear within the next 100 years [58].

Surface water $\mathrm{NO}_{3}{ }^{-}$concentrations were heavily weighted on the first axis of the RDA (Figure 3), indicative of the strong influence climatic parameters have on the cycling of $\mathrm{N}$ in the Georgia Basin. Nitrate concentrations were found to be significantly different between the three biogeoclimatic zones with the $\mathrm{CWH}$ zone having significantly greater concentrations than the $\mathrm{MH}$ and AT zones $\left(3.77 \mu \mathrm{eq} \mathrm{L}^{-1}, 1.23 \mu \mathrm{eq} \mathrm{L}^{-1}\right.$, and $0.68 \mu \mathrm{eq} \mathrm{L}^{-1}$, resp.; $\mathrm{H}_{2,54}=17.19, P<0.05$; Table 3). The influence of increased temperature and precipitation on $\mathrm{N}$ dynamics is difficult to determine as many climatic, biological, and physical processes govern the cycling of $\mathrm{N}$ in ecosystems and the expected time scale of such changes has yet to be determined [59]. In the current study, statistical analysis of $\mathrm{NO}_{3}{ }^{-}$suggests that temperature and precipitation play an integral role in the $\mathrm{N}$ dynamics of high-elevation catchments.

Park et al. [60] in their study of watersheds in Northeast Asia found that $\mathrm{NO}_{3}{ }^{-}$concentrations in stream waters were the greatest during periods of high rainfall. They attributed this finding to the increased wet deposition of $\mathrm{N}$ resulting from increased wash-out in precipitation, also supported by Williams et al. $[6,61]$ in their study of high-elevation catchments in the Colorado Front Range, USA. Although not significant, in the Georgia Basin, precipitation differed between the three biogeoclimatic zones with the $\mathrm{CWH}$ zone having greater MAP than the MH and AT zones $\left(3617 \mathrm{~mm} \mathrm{yr}^{-1}\right.$, $3488 \mathrm{~mm} \mathrm{yr}^{-1}$, and $3218 \mathrm{~mm} \mathrm{yr}^{-1}$, resp.; Table 3). Modelled $\mathrm{N}$ deposition, however, did vary significantly with the $\mathrm{CWH}$ zone receiving significantly greater deposition $\left(10.4 \mathrm{~kg} \mathrm{ha}^{-1} \mathrm{yr}^{-1}\right)$ than the MH $\left(8.48 \mathrm{~kg} \mathrm{ha}^{-1} \mathrm{yr}^{-1}\right)$ and AT (5.80 $\left.\mathrm{kg} \mathrm{ha}^{-1} \mathrm{yr}^{-1}\right)$ zones $\left(\mathrm{H}_{2,54}=9.57, P<0.05\right.$; Table 3$)$. Changes in precipitation volume, seasonality, and $\mathrm{N}$ oxides $\left(\mathrm{NO}_{x}\right)$ emissions under future conditions may potentially lead to increased $\mathrm{N}$ deposition and elevated $\mathrm{NO}_{3}{ }^{-}$concentrations in high-elevation lakes in the Georgia Basin. However, in a recent report by Metro Vancouver [62], $\mathrm{NO}_{x}$ emissions are projected to decrease until 2020 but are then predicted to remain stable (at approximately 45 kilotonnes $\mathrm{yr}^{-1}$ ) due primarily to increased marine traffic in southwest British Columbia.

Higher temperatures may intensify $\mathrm{NO}_{3}{ }^{-}$leaching from catchment soils owing to increased rates of $\mathrm{N}$ mineralization by soil microbes $[37,63]$. Increased nitrification rates have been observed in the Catskill Mountains of New York under increased temperature resulting in greater leaching of $\mathrm{NO}_{3}{ }^{-}$ into surface waters [63]. Several studies have suggested that increased $\mathrm{NO}_{3}{ }^{-}$transport has resulted in episodic and chronic acidification of acid-sensitive surface waters $[37,64]$. In the Georgia Basin, surface waters in the AT biogeoclimatic zone may be most influenced by increased temperature induced $\mathrm{NO}_{3}{ }^{-}$leaching because of its present low temperatures and low $\mathrm{NO}_{3}{ }^{-}$concentrations compared to the CWH and $\mathrm{MH}$ zones.

In contrast, enhanced $\mathrm{N}$ assimilation by terrestrial plant life may limit $\mathrm{NO}_{3}{ }^{-}$entering aquatic systems through soil leaching and runoff $[47,59,65]$. Nitrogen is a limiting nutrient for terrestrial systems and if future projections of increased terrestrial productivity occur in the AT and $\mathrm{MH}$ biogeoclimatic zones $[41,52], \mathrm{NO}_{3}{ }^{-}$export to surface waters may be alleviated by the increased demand by alpine and subalpine vegetation. However, when the demand for $\mathrm{N}$ is reached or exceeded, $\mathrm{NO}_{3}{ }^{-}$concentrations in surface waters are hypothesised to increase $[61,66]$.

Accurately predicting the response of $\mathrm{N}$ and DOC to climate change is arguably more difficult than other chemical constituents in surface waters because of the extremely complex interactions with biological, physical, and climate related systems. It is therefore important that increased monitoring and research be carried out in high-elevation and alpine environments.

\subsection{Climate Change and Its Influence on Soil Base Cation} Weathering Rates. Weathering rates in alpine and highelevation catchments are typically very low because of their thin soils, low temperatures, highly resistant bedrock, and small catchment to lake ratios [67-70]. Water residence times in alpine and high-elevation soils also tend to be quite low, decreasing the contact time between water and weatherable 


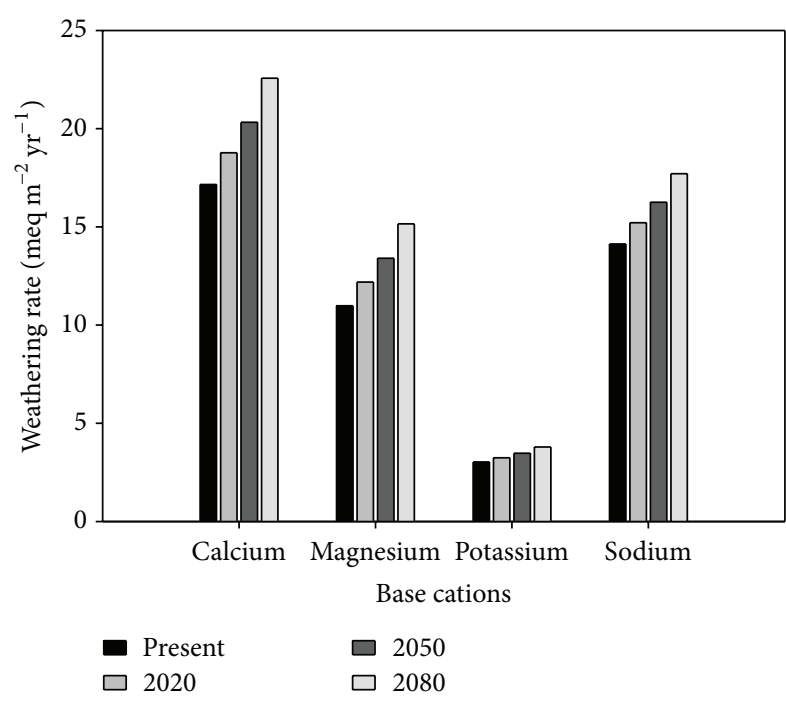

FIgURE 4: Average PROFILE weathering rates for calcium $\left(\mathrm{Ca}^{2+}\right)$, magnesium $\left(\mathrm{Mg}^{2+}\right)$, potassium $\left(\mathrm{K}^{+}\right)$, and sodium $\left(\mathrm{Na}^{+}\right)$for soil study sites $(n=11)$ under present day and future climate change conditions in the Georgia Basin, British Columbia. Future weathering rates were based on temperature increases of $1.1^{\circ} \mathrm{C}, 2.1^{\circ} \mathrm{C}$, and $3.4^{\circ} \mathrm{C}$ for the years 2020,2050 , and 2080 , respectively.

minerals [68]. Studies in the Swiss Alps have shown decreased weathering rates with increasing altitude [68]. Similarly, a study by Mongeon et al. [28] at 19 sites in the Georgia Basin suggested that weathering rates were the lowest at the highest elevations, owing to their shallow soils and low quantities of easily weatherable minerals. Similarly, in the present study, lake concentrations of $\mathrm{Na}^{+}$and silicon $(\mathrm{Si}$; typically associated with weathering rates) were significantly different between the three biogeoclimatic zones. The highelevation AT biogeoclimatic zone had significantly lower $\mathrm{Na}^{+}$ and $\mathrm{Si}$ concentrations than the $\mathrm{MH}$ and $\mathrm{CWH}$ zones $\left(\mathrm{H}_{2,54}=\right.$ 12.51, $P<0.05$ and $\mathrm{H}_{2,54}=10.01, P<0.05$, resp.; Table 3), indicative of lower weathering rates. As a result, mountain lakes are typically very dilute and sensitive to climate change [71].

Increased soil base cation weathering rates with higher temperature have been widely reported $[15,59,72,73]$. In the current study, PROFILE was used to estimate future weathering rates for the 11 high-elevation study catchments in the Georgia Basin (9 located in the MH biogeoclimatic zone and 2 located in the $\mathrm{CWH}$ biogeoclimatic zone) under predicted average temperature increases of $1.1^{\circ} \mathrm{C}, 2.1^{\circ} \mathrm{C}$, and $3.4^{\circ} \mathrm{C}$ for 2020, 2050, and 2080. In all three simulations, estimated weathering rates increased from present day conditions, with total base cation flux estimated to increase by $9.1 \%$ in 2020 , $18 \%$ in 2050 , and $30.7 \%$ in 2080 (Figure 4 ). The approximately $9 \%$ increase per $1^{\circ} \mathrm{C}$ in temperature is consistent with previous studies $[73,74]$. The importance of temperature on mineral weathering rates has been debated; while laboratory studies show a strong dependence on temperature, field studies are often obscured by other environmental factors that covary with temperature [75]. Nonetheless, several studies have reported field-based temperature dependence on natural weathering $[73,76]$. In the current study, $\mathrm{Ca}^{2+}$ was the dominant weathered element, followed by $\mathrm{Mg}^{2+}, \mathrm{Na}^{+}$, and $\mathrm{K}^{+}$ (Figure 4). This may be the result of the high concentrations of calcic-plagioclase in the catchments (average of 13.2\%) which is considered extremely unstable and, as such, is easily weathered [77].

Mineral weathering ultimately depends on soil mineralogy, and chemical kinetics dictate that the dissolution rate of minerals per unit surface area is temperature dependent [78]. Moreover, the active mineral surface area is influenced by soil moisture and acidity [79]. In the current study, other climaterelated controls on weathering rates, such as soil moisture $[73,78]$, could potentially offset increases due to temperature; however, soil moisture (on an annual basis) is not expected to change much under A2 climate change in the Georgia Basin given the increase in precipitation (Figure 2). Higher temperatures will not only accelerate the dissolution of minerals from bedrock and soils $[23,59]$ but will also promote the production of organic acids that can further influence base cation weathering rates [80]. Predicted decreases in glacier, ice, and snow cover will expose greater proportions of soil and bedrock to climatic parameters and freeze-thaw cycles $[81,82]$. Recently exposed bedrock is considered to be extremely reactive and thus extremely sensitive to chemical weathering [8].

In the Central Alps, Rogora et al. [59] have suggested that the recent increase in solute concentrations of highelevation lakes can be attributed to the increased transport of weathered minerals associated with higher temperatures, lower snow cover, and enhanced weathering rates. Greater export of base cations from catchments to lakes will alter the chemical composition of surface waters such as ANC [83] and may modify the acid-sensitivity of surface waters.

\subsection{Climate Change and Its Influence on the Acid-Sensitivity of} High-Elevation Lakes. Determining how climate change will affect the acidity and acid-sensitivity of high-elevation lakes is difficult as other factors aside from climate parameters (i.e., land cover, lithology) play an integral role. A recent study on the acidity of high-elevation lakes in the Georgia Basin $(n=72)$ indicated that $20 \%$ of the study lakes had $\mathrm{pH}$ levels less than 6 [12]. In the present study, results from the $\mathrm{RDA}$ analysis indicated that $\mathrm{pH}$ was primarily attributed to climatic parameters (-0.967; Figure 2). As such, differences in surface water $\mathrm{pH}$ between the biogeoclimatic zones were observed with the $\mathrm{CWH}$ zone having significantly lower $\mathrm{pH}$ levels (6.07) than the MH (6.45) and AT (6.46) biogeoclimatic zones $\left(\mathrm{H}_{2,54}=9.14, P=0.01\right.$; Table 3$)$.

The $\mathrm{pH}$ of high-elevation lakes has been reported to decrease with increasing elevation [68]. The increase in $\mathrm{pH}$ with elevation in the Georgia Basin has been attributed to the lower levels of atmospheric ( $\mathrm{S}$ and $\mathrm{N}$ ) deposition at higher elevations as well as the decreased production of acidic organic anions [12]. Modelled N and S deposition were greater in the lower elevation CWH zone and decreased significantly through the higher elevation $\mathrm{MH}$ and AT zones $\left(\mathrm{H}_{2,54}=9.57, P<0.05\right.$ and $\mathrm{H}_{2,54}=17.25, P<0.05$, resp.; Table 3) in concert with DOC concentrations. As 
such, natural acidification resulting from increased terrestrial productivity and organic acid production [37] may play an important role, especially in the $\mathrm{MH}$ and AT zones. Furthermore, with increased warming, surface waters located in the AT zone may experience episodic acidification resulting from $\mathrm{NO}_{3}{ }^{-}$inputs from melting glaciers and runoff from catchment soils $[3,37]$.

It has been suggested that surface water $\mathrm{pH}$ and $\mathrm{ANC}$ in the Georgia Basin are significantly influenced by the amount of ice and glacier cover in the surrounding catchment with greater $\mathrm{pH}$ and $\mathrm{ANC}$ occurring in glacier dominated catchments [12]. Glacial melt waters have been shown to be high in base cation concentrations [84]. Increasing temperatures will alter the natural dynamics of glacier accumulation and recession [85] potentially altering the $\mathrm{pH}, \mathrm{ANC}$, and $\mathrm{CL}(\mathrm{A})$ of these surface waters through the increased transport of base rich glacial melt waters. Another result of retreating glaciers and decreasing snowpack is the greater proportion of the lake catchments becoming exposed and, consequently, influenced by weathering processes $[59,81,82]$. Higher temperatures and precipitation leading to increased weathering have been directly linked to the increased transport of base cations and other solutes from catchments to surface waters [59, $72,86]$. Weathering rates in the Georgia Basin were predicted to increase under future climate conditions and such increases may alter the CL(A) of high-elevation lakes in this region.

The critical load of acidity was developed to characterize the sensitivity of surface waters to acidification from atmospheric deposition. It is defined as "a quantitative estimate of an exposure to one or more pollutants below which significant harmful effects on specified sensitive elements of the environment do not occur according to present knowledge" [87]. In the Georgia Basin, approximately $18 \%$ of the lakes surveyed $(n=72)$ received $S$ deposition in excess of their CL(A) [12]. Critical loads are influenced by climate change and previous studies have suggested that increased temperature and precipitation lead to increased CL(A) [88]. Accordingly, the number of lakes currently exceeding their $\mathrm{CL}(\mathrm{A})$ in the Georgia Basin may decrease; the determining factor will be whether enhanced weathering of base cations from the catchment soils and bedrock are sufficient to buffer changes in natural acidity and anthropogenic inputs from atmospheric $\mathrm{S}$ and $\mathrm{N}$ deposition.

\section{Conclusions}

It is difficult to predict how the hydrochemistry of surface waters will be influenced by climate change. Temperature and precipitation are expected to increase based on the CGCM2 model under the IPCC A2 scenario. These increases may potentially result in significant changes in the chemical composition of surface waters in high-elevation regions of the Georgia Basin.

Biogeoclimatic zones are characterized by a specific range of temperature and precipitation regimes; based on the current chemical composition of lakes in each of these zones, changes in DOC (associated trace metals) and $\mathrm{NO}_{3}{ }^{-}$ will most likely be observed, resulting from increased terrestrial productivity and greater runoff originating from melting glacier and snow cover. Such changes could alter the $\mathrm{pH}$ of surface waters through the natural acidification process associated with organic acid production and by episodic acidification. Base cation weathering rates were predicted to increase under future climate. The greater flux of these elements into surface waters may influence the acid-sensitivity of high-elevation lakes in the Georgia Basin. The ratio between increased transport of base cations into surface waters, deposition levels, and increased acidifying components from organic anion production will ultimately determine whether lakes will continue to be susceptible to acidification.

Future monitoring is essential in assessing the sensitivity of high-elevation lakes to climate change both in the Georgia Basin and in mountainous regions worldwide. Increased monitoring efforts are imperative in developing accurate estimates of temperature and precipitation changes in these complex topographical regions and the potential ramifications of climate change on the acid-sensitivity of high-elevation surface waters.

\section{Conflict of Interests}

The authors declare that no competing interests exist.

\section{Acknowledgments}

This research was funded both by the Environment Canada Georgia Basin Action Plan and by the Environment Canada Acid Rain Program. This research was also undertaken, in part, thanks to funding from the Canada Research Chairs Program and an NSERC Discovery grant. Thanks go to all field assistants and laboratory technicians involved in the collection and analysis of soil and water samples and to Dr. John Gibson of the Alberta Research Council for delineating catchment and lake boundaries. Access was granted by BC Parks to sample lakes within the boundaries of provincial parks. Special thanks go to the late Beverley A. Raymond who initiated the project and contributed greatly to the site selection.

\section{References}

[1] M. Beniston, "Climatic change in mountain regions: a review of possible impacts," Climatic Change, vol. 59, no. 1-2, pp. 5-31, 2003.

[2] M. Beniston, "Mountain weather and climate: a general overview and a focus on climatic change in the Alps," Hydrobiologia, vol. 562, no. 1, pp. 3-16, 2006.

[3] J. S. Baron, T. M. Schmidt, and M. D. Hartman, "Climateinduced changes in high elevation stream nitrate dynamics," Global Change Biology, vol. 15, no. 7, pp. 1777-1789, 2009.

[4] M. Beniston, H. F. Diaz, and R. S. Bradley, "Climatic change at high elevation sites: an overview," Climatic Change, vol. 36, no. 3-4, pp. 233-251, 1997.

[5] K. A. Koinig, R. Schmidt, S. Sommaruga-Wograth, R. Tessadri, and R. Psenner, "Climate change as the primary cause for $\mathrm{pH}$ 
shifts in a high alpine lake," Water, Air and Soil Pollution, vol. 104, pp. 167-180, 1997.

[6] M. W. Williams, M. Losleben, N. Caine, and D. Greenland, "Changes in climate and hydrochemical responses in a highelevation catchment in the Rocky Mountains, USA," Limnology and Oceanography, vol. 41, no. 5, pp. 939-946, 1996.

[7] J. Melack, J. Dozier, C. R. Goldman, D. Greenland, A. Milner, and R. J. Naiman, "Effects of climate change on inland waters of the Pacific Coastal mountains and Western Great Basin of North America," Hydrological Processes, vol. 11, no. 8, pp. 971992, 1997.

[8] S. N. Chillrud, F. L. Pedrozo, P. F. Temporetti, H. F. Planas, and P. N. Froelich, "Chemical weathering of phosphate and germanium in glacial meltwater streams: effects of subglacial pyrite oxidation," Limnology and Oceanography, vol. 39, no. 5, pp. 1130-1140, 1994.

[9] F. R. Hauer, J. S. Baron, D. H. Campbell et al., "Assessment of climate change and freshwater ecosystems of the Rocky Mountains, USA and Canada," Hydrological Processes, vol. 11, no. 8, pp. 903-924, 1997.

[10] M. W. Williams, P. D. Brooks, and T. Seastedt, "Nitrogen and carbon soil dynamics in response to climate change in a highelevation ecosystem in the Rocky Mountains, U.S.A.," Arctic and Alpine Research, vol. 30, no. 1, pp. 26-30, 1998.

[11] K. Klanderud and $\varnothing$. Totland, "Simulated climate change altered dominance hierarchies and diversity of an alpine biodiversity hotspot," Ecology, vol. 86, no. 8, pp. 2047-2054, 2005.

[12] D. Strang, J. Aherne, and D. P. Shaw, "The hydrochemistry of high-elevation lakes in Georgia Basin, British Columbia, Canada," Journal of Limnology, vol. 69, no. 1, pp. 56-66, 2010.

[13] H. G. Hengeveld, "The science of climate change," in Responding to Global Climate Change in British Columbia and Yukon, E. Taylor and B. Taylor, Eds., vol. 1 of Canada Country Study: Climate Impacts and Adaptation, p. 363, Environment Canada, 1997.

[14] O. Slaymaker, "Climate change and erosion processes in mountain regions of Western Canada," Mountain Research \& Development, vol. 10, no. 2, pp. 171-182, 1990.

[15] P. Warfvinge and H. Sverdrup, "Calculating critical loads of acid deposition with profile. A steady-state soil chemistry model," Water, Air, and Soil Pollution, vol. 63, no. 1-2, pp. 119-143, 1992.

[16] C. Daly, R. P. Neilson, and D. L. Phillips, "A statisticaltopographic model for mapping climatological precipitation over mountainous terrain," Journal of Applied Meteorology, vol. 33, no. 2, pp. 140-158, 1994.

[17] D. Meidinger and J. Pojar, Ecosystems of British Columbia, BC Ministry of Forests, 1991.

[18] T. Wang, A. Hamann, D. L. Spittlehouse, and S. N. Aitken, "Development of scale-free climate data for Western Canada for use in resource management," International Journal of Climatology, vol. 26, no. 3, pp. 383-397, 2006.

[19] G. M. Flato, G. J. Boer, W. G. Lee et al., "The Canadian centre for climate modelling and analysis global coupled model and its climate," Climate Dynamics, vol. 16, no. 6, pp. 451-467, 2000.

[20] N. Nakicenovic and R. Swart, Special Report on Emissions Scenarios: A Special Report of Working Group III of the Intergovernmental Panel on Climate Change, Cambridge University Press, Cambridge, UK, 2000.

[21] B. de Vos, B. Vandecasteele, J. Deckers, and B. Muys, "Capability of loss-on-ignition as a predictor of total organic carbon in non-calcareous forest soils," Communications in Soil Science and Plant Analysis, vol. 36, no. 19-20, pp. 2899-2921, 2005.
[22] M. Raudsepp, E. Pani, and G. M. Dipple, "Measuring mineral abundance in skarn. I. Rietveld method using X-ray powderdiffraction data," Canadian Mineralogist, vol. 37, no. 1, pp. 1-15, 1999.

[23] B. F. Turner, A. F. White, and S. L. Brantley, "Effects of temperature on silicate weathering: Solute fluxes and chemical weathering in a temperate rain forest watershed, Jamieson Creek, British Columbia," Chemical Geology, vol. 269, no. 1-2, pp. 62-78, 2010.

[24] A. Barkman and M. Alveteg, "Effects of data uncertainty in the Swedish critical load assessment for forest soils," Water, Air, and Soil Pollution, vol. 125, no. 1, pp. 133-156, 2001.

[25] C. van der Salm, P. Adamo, M. R. Bianco, and P. Violante, "Assessment of the regional variation in weathering rates of loess and clay soils in the Netherlands," Water, Air, and Soil Pollution, vol. 131, no. 1-4, pp. 217-243, 2001.

[26] C. J. Whitfield, S. A. Watmough, J. Aherne, and P. J. Dillon, "A comparison of weathering rates for acid-sensitive catchments in Nova Scotia, Canada and their impact on critical load calculations," Geoderma, vol. 136, no. 3-4, pp. 899-911, 2006.

[27] J. Aherne, A. Mongeon, and S. A. Watmough, "Temporal and spatial trends in precipitation chemistry in the Georgia Basin, British Columbia," Journal of Limnology, vol. 69, no. 1, pp. 4-10, 2010.

[28] A. Mongeon, J. Aherne, and S. A. Watmough, "Steady-state critical loads of acidity for forest soils in the Georgia Basin, British Columbia," Journal of Limnology, vol. 69, no. 1, pp. 193200, 2010.

[29] C. Di Cenzo and M. Lepage, "Application of CMAQ over the Pacific Northwest to determine the significance of the international trans-boundary flows of air contaminants," in Proceedings of the 2nd Annual CMAS Models-3 User's Conference-One Atmosphere, One Community, One Modelling System: Models-3, p. 5, Research Triangle Park, Raleigh, NC, USA, October 2003.

[30] G. P. Quinn and M. J. Keough, Experimental Design and Data Analysis for Biologists, Cambridge University Press, New York, NY, USA, 2002.

[31] A. Marchetto, "Factors affecting water chemistry of Alpine lakes," Aquatic Sciences, vol. 57, no. 1, pp. 81-89, 1995.

[32] S. Stendera and R. K. Johnson, "Multiscale drivers of water chemistry of boreal lakes and streams," Environmental Management, vol. 38, no. 5, pp. 760-770, 2006.

[33] B. G. Parsons, S. A. Watmough, P. J. Dillon, and K. M. Somers, "Relationships between lake water chemistry and benthic macroinvertebrates in the Athabasca Oil Sands Region, Alberta," Journal of Limnology, vol. 69, no. 1, pp. 118-125, 2010.

[34] B. Taylor, "The climates of British Columbia and Yukon," in Responding to Global Climate Change in British Columbia and Yukon, E. Taylor and B. Taylor, Eds., vol. 1 of Canada Country Study: Climate Impacts and Adaptation, p. 363, Environment Canada, 1997.

[35] Intergovernmental Panel on Climate Change (IPCC), Climate Change 2007: The Physical Science Basis, Cambridge University Press, Cambridge, UK, 2007.

[36] J. R. Brook, P. J. Samson, and S. Sillman, "A meteorology-based approach to detecting the relationships between changes in $\mathrm{SO}_{2}$ emission rates and precipitation concentrations of sulphate," Journal of Applied Meteorology, vol. 33, pp. 1050-1066, 1994.

[37] C. T. Driscoll, G. B. Lawrence, A. J. Bulger et al., "Acidic deposition in the northeastern United States: sources and inputs, ecosystem effects, and management strategies," BioScience, vol. 51, no. 3, pp. 180-198, 2001. 
[38] D. Fowler, I. D. Leith, J. Binnie et al., "Orographic enhancement of wet deposition in the United Kingdom: continuous monitoring," Water, Air, and Soil Pollution, vol. 85, no. 4, pp. 2107-2112, 1995.

[39] M. Ito, M. J. Mitchell, and C. T. Driscoll, "Spatial patterns of precipitation quantity and chemistry and air temperature in the Adirondack region of New York," Atmospheric Environment, vol. 36, no. 6, pp. 1051-1062, 2002.

[40] R. Hebda, "Impact of climate change on the biogeoclimatic zones of British Columbia and Yukon," in Responding to Global Climate Change in British Columbia and Yukon-Volume 1 of the Canada Country Study: Climate Impacts and Adaptation, E. Taylor and B. Taylor, Eds., p. 363, Environment Canada, 1997.

[41] P. G. Krannitz and S. Kesting, "Impacts of climate change on the plant communities of Alpine ecosystems," in Responding to Global Climate Change in British Columbia and Yukon-Volume 1 of the Canada Country Study: Climate Impacts and Adaptation, E. Taylor and B. Taylor, Eds., p. 363, Environment Canada, 1997.

[42] S. L. Shafer, P. J. Bartlein, and R. S. Thompson, "Potential changes in the distributions of western North America tree and shrub taxa under future climate scenarios," Ecosystems, vol. 4, no. 3, pp. 200-215, 2001.

[43] R. F. Wright and A. Jenkins, "Climate change as a confounding factor in reversibility of acidification: RAIN and CLIMEX projects," Hydrology and Earth System Sciences, vol. 5, no. 3, pp. 477-486, 2001.

[44] T. R. Moore and M. Dalva, "Some controls on the release of dissolved organic carbon by plant tissues and soils," Soil Science, vol. 166, no. 1, pp. 38-47, 2001.

[45] T. K. Kratz, K. E. Webster, C. J. Bowser, J. J. Magnuson, and B. J. Benson, "The influence of landscape position on lakes in northern Wisconsin," Freshwater Biology, vol. 37, no. 1, pp. 209217, 1997.

[46] C. D. Evans, D. T. Monteith, and D. M. Cooper, "Long-term increases in surface water dissolved organic carbon: observations, possible causes and environmental impacts," Environmental Pollution, vol. 137, no. 1, pp. 55-71, 2005.

[47] E. Stuchlík, J. Kopáček, J. Fott, and Z. Hořická, "Chemical composition of the Tatra Mountain lakes: response to acidification," Biologia, Bratislava, vol. 61, pp. S11-S20, 2006.

[48] L. Roberts, "How fast can trees migrate?" Science, vol. 243, no. 4892, pp. 735-737, 1989.

[49] S. Hughes, B. Reynolds, and J. D. Roberts, “The influence of land management on concentrations of dissolved organic carbon and its effects on the mobilization of aluminium and iron in podzol soils in mid-Wales," Soil Use \& Management, vol. 6, no. 3, pp. 137-145, 1990.

[50] R. K. Dixon, S. Brown, R. A. Houghton, A. M. Solomon, M. C. Trexler, and J. Wisniewski, "Carbon pools and flux of global forest ecosystems," Science, vol. 263, no. 5144, pp. 185-190, 1994.

[51] B. R. Parker, R. D. Vinebrooke, and D. W. Schindler, "Recent climate extremes alter alpine lake ecosystems," Proceedings of the National Academy of Sciences of the United States of America, vol. 105, no. 35, pp. 12927-12931, 2008.

[52] P. J. Burton and S. G. Cummong, "Potential effects of climatic change on some western Canadian forests, based on phenological enhancement to a patch model of forest succession," Water, Air, and Soil Pollution, vol. 82, no. 1-2, pp. 401-414, 1995.

[53] R. J. Hebda, "The future of British Columbias Flora," in Biodiversity in British Columbia: Our Changing Environmen, L. E. Harding and E. McCullum, Eds., p. 426, Canadian Wildlife Service, Environment Canada, British Columbia, Canada, 1994.
[54] H. Borg, "Trace metals in Swedish natural fresh waters." Hydrobiologia, vol. 101, pp. 27-34, 1983.

[55] V. N. Bashkin, Modern Biogeochemistry, Kluwer Academic Publishers, New York, NY, USA, 2003.

[56] J. G. Wiener and D. J. Spry, "Toxicological significance of mercury in freshwater fish," in Environmental Contaminants in Wildlife: Interpreting Tissue Concentrations, W. N. Beyer, G. H. Heinz, and A. W. Redmon-Norwood, Eds., p. 512, Lewis Publishers, Boca Raton, Fla, USA, 1996.

[57] H. Thies, U. Nickus, V. Mair et al., "Unexpected response of high alpine lake waters to climate warming," Environmental Science and Technology, vol. 41, no. 21, pp. 7424-7429, 2007.

[58] I. J. Walker and R. Sydneysmith, "British Columbia," in From Impacts to Adaptation: Canada in a Changing Climate 2007, D. S. Lemmen, F. J. Warren, J. Lacroix, and E. Bush, Eds., p. 448, Government of Canada, Ottawa, Canada, 2008.

[59] M. Rogora, R. Mosello, and S. Arisci, "The effect of climate warming on the hydrochemistry of Alpine lakes," Water, Air, and Soil Pollution, vol. 148, no. 1-4, pp. 347-361, 2003.

[60] J. H. Park, L. Duan, B. Kim, M. J. Mitchell, and H. Shibata, "Potential effects of climate change and variability on watershed biogeochemical processes and water quality in Northeast Asia," Environment International, vol. 36, no. 2, pp. 212-225, 2010.

[61] M. W. Williams, J. S. Baron, N. Caine, R. Sommerfeld, and R. Sanford Jr., "Nitrogen saturation in the rocky mountains," Environmental Science and Technology, vol. 30, no. 2, pp. 640646, 1996.

[62] Metro Vancouver, 2005 Lower Fraser Valley Air Emissions Inventory and Forecast and Backcast, Metro Vancouver, Policy and Planning Department, Air Quality Policy and Management Division, 2007.

[63] P. S. Murdoch, D. A. Burns, and G. B. Lawrence, "Relation of climate change to the acidification of surface waters by nitrogen deposition," Environmental Science and Technology, vol. 32, no. 11, pp. 1642-1647, 1998.

[64] K. B. Piatek, M. J. Mitchell, S. R. Silva, and C. Kendall, "Sources of nitrate in snowmelt discharge: evidence from water chemistry and stable isotopes of nitrate," Water, Air, and Soil Pollution, vol. 165, no. 1-4, pp. 13-35, 2005.

[65] P. S. Murdoch, J. S. Baron, and T. L. Miller, "Potential effects of climate change on surface-water quality in North America," Journal of the American Water Resources Association, vol. 36, no. 2, pp. 347-366, 2000.

[66] J. D. Aber, K. J. Nadelhoffer, P. Steudler, and J. M. Melillo, "Nitrogen saturation in northern forest ecosystems," BioScience, vol. 39, no. 6, pp. 378-386, 1989.

[67] D. W. Schindler, "The significance of in-lake production of alkalinity," Water, Air, and Soil Pollution, vol. 30, no. 3-4, pp. 931944, 1986.

[68] J. I. Drever and J. Zobrist, "Chemical weathering of silicate rocks as a function of elevation in the southern Swiss Alps," Geochimica et Cosmochimica Acta, vol. 56, no. 8, pp. 3209-3216, 1992.

[69] J. Kopáček, D. Hardekopf, V. Majer, P. Pšenáková, E. Stuchlík, and J. Veselý, "Response of alpine lakes and soils to changes in acid deposition: the MAGIC model applied to the Tatra Mountain region, Slovakia-Poland," Journal of Limnology, vol. 63, no. 1, pp. 143-156, 2004.

[70] M. Posch, U. Eggenburger, D. Kurz, and B. Rihm, A Weathering Rate Calculation Model and the Generalized First-Order Acidity 
Balance (FAB) Model Applied to Alpine Lake Catchments, Environmental Studies no. 0709, Federal Office for the Environment, Berne, Switzerland, 2007.

[71] R. Psenner and R. Schmidt, "Climate-driven $\mathrm{pH}$ control of remote alpine lakes and effects of acid deposition," Nature, vol. 356, no. 6372, pp. 781-783, 1992.

[72] J. Adams, "Weathering and glacial cycles," Nature, vol. 373, p. 110, 1995.

[73] A. F. White and A. E. Blum, "Effects of climate on chemicalweathering in watersheds," Geochimica et Cosmochimica Acta, vol. 59, no. 9, pp. 1729-1747, 1995.

[74] P. V. Brady, "The effect of silicate weathering on global temperature and atmospheric $\mathrm{CO}_{2}$," Journal of Geophysical Research, vol. 96, no. 11, pp. 18-106, 1991.

[75] L. R. Kump, S. L. Brantley, and M. A. Arthur, "Chemical weathering, atmospheric $\mathrm{CO}_{2}$, and climate," Annual Review of Earth and Planetary Sciences, vol. 28, pp. 611-667, 2000.

[76] M. A. Velbel, "Temperature dependence of silicate weathering in nature: how strong a negative feedback on longterm accumulation of atmospheric $\mathrm{CO}_{2}$ and global greenhouse warming?" Geology, vol. 21, no. 12, pp. 1059-1062, 1993.

[77] S. S. Goldich, "A study in rock weathering," The Journal of Geology, vol. 46, no. 1, pp. 17-58, 1938.

[78] H. U. Sverdrup, The Kinetics of Base Cation Release due to Chemical Weathering, Lund University Press, Lund, Sweden, 1990.

[79] H. U. Sverdrup, "Chemical weathering of soil minerals and the role of biological processes," Fungal Biology Reviews, vol. 23, no. 4, pp. 94-100, 2009.

[80] R. E. Stauffer, "Granite weathering and the sensitivity of alpine lakes to acid deposition," Limnology and Oceanography, vol. 35, no. 5, pp. 1112-1134, 1990.

[81] R. F. Wright and D. W. Schindler, "Interaction of acid rain and global changes: effects on terrestrial and aquatic ecosystems," Water, Air, and Soil Pollution, vol. 85, no. 1, pp. 89-99, 1995.

[82] B. L. Skjelkvale and R. F. Wright, "Mountain lakes: sensitivity to acid deposition and global climate change," Ambio, vol. 27, no. 4, pp. 280-286, 1998.

[83] D. F. Charles, Ed., Acidic Deposition and Aquatic Ecosystems. Regional Case Studies, Springer, New York, NY, USA, 1991.

[84] S. P. Anderson, J. I. Drever, and N. F. Humphrey, "Chemical weathering in glacial environments," Geology, vol. 25, no. 5, pp. 399-402, 1997.

[85] Intergovernmental Panel on Climate Change (IPCC), Climate Change 2007: Climate Change Impacts, Adaptation and Vulnerability. Summary for Policy Makers, Cambridge University Press, Cambridge, UK, 2007.

[86] R. H. Gwiazda and W. S. Broecker, "The separate and combined effects of temperature, soil $\mathrm{pCO}_{2}$, and organic acidity on silicate weathering in the soil environment: formulation of a model and results," Global Biogeochemical Cycles, vol. 8, no. 2, pp. 141-155, 1994.

[87] J. Nilsson and P. Grennfelt, Critical Loads for Sulphur and Nitrogen. Miljørapport 1988:I5, NORD 1998:097, Nordic Council of Ministers, Copenhagen, Denmark, 1998.

[88] M. Posch, "Impacts of climate change on critical loads and their exceedances in Europe," Environmental Science and Policy, vol. 5, no. 4, pp. 307-317, 2002. 

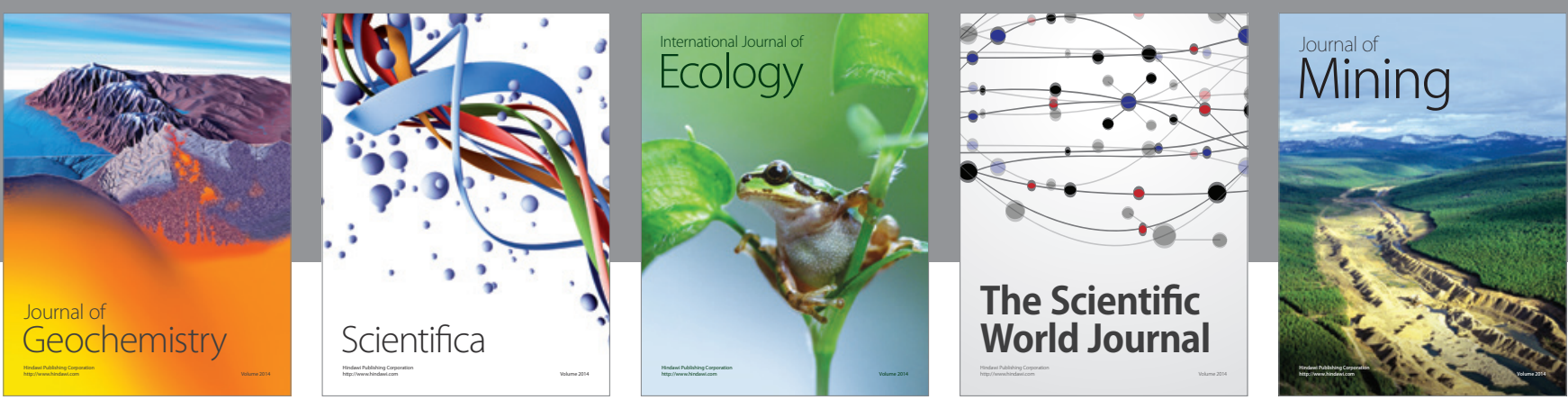

The Scientific World Journal
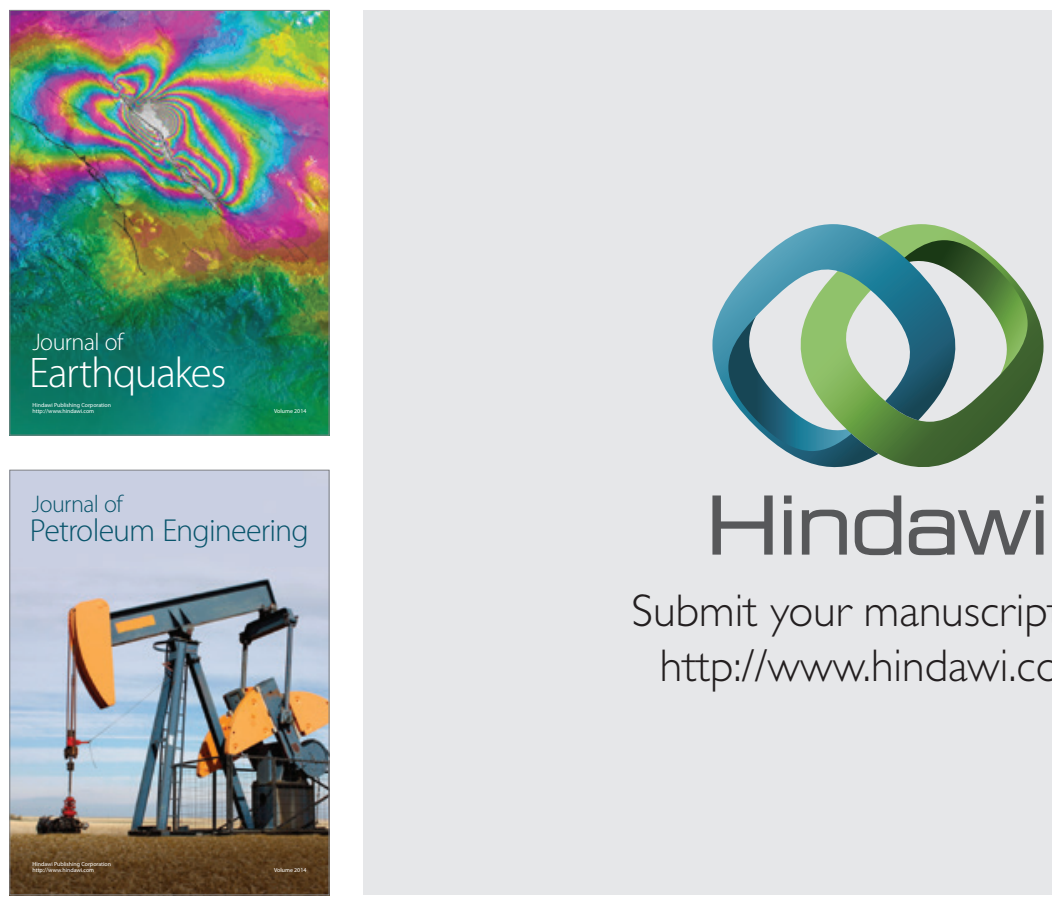

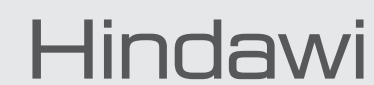

Submit your manuscripts at

http://www.hindawi.com
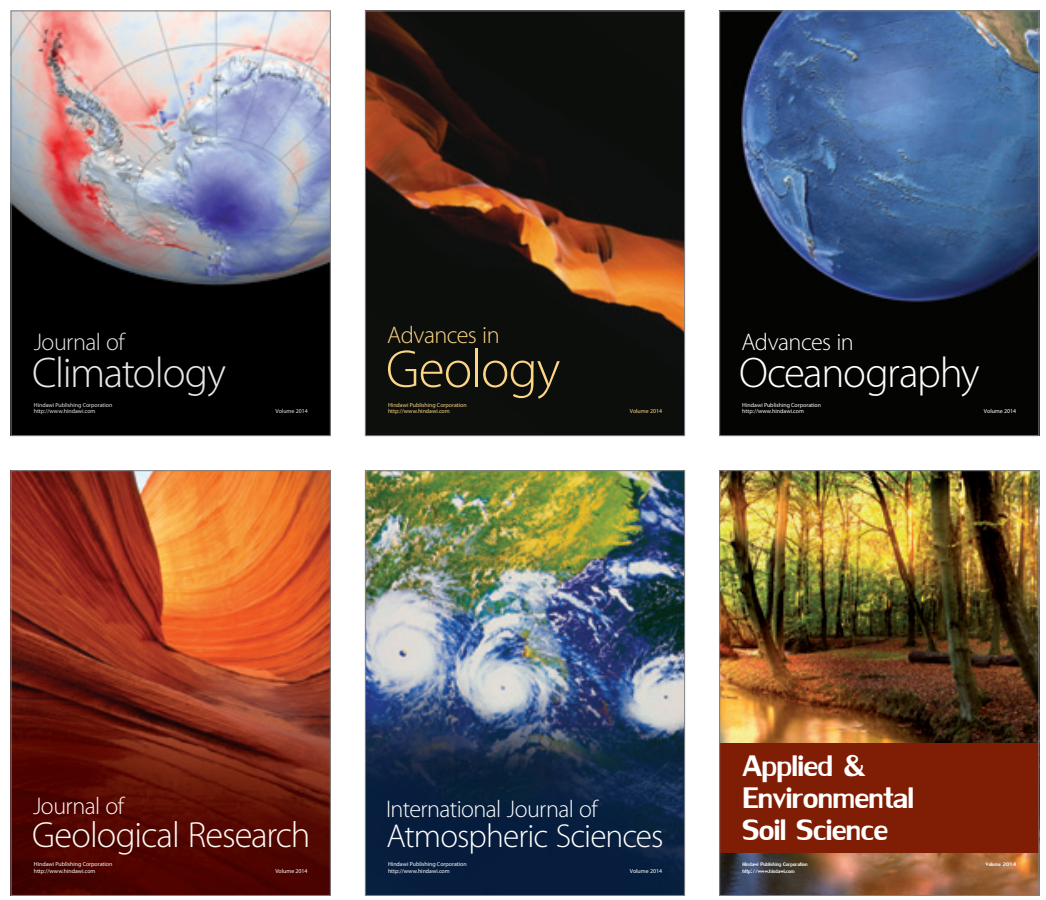
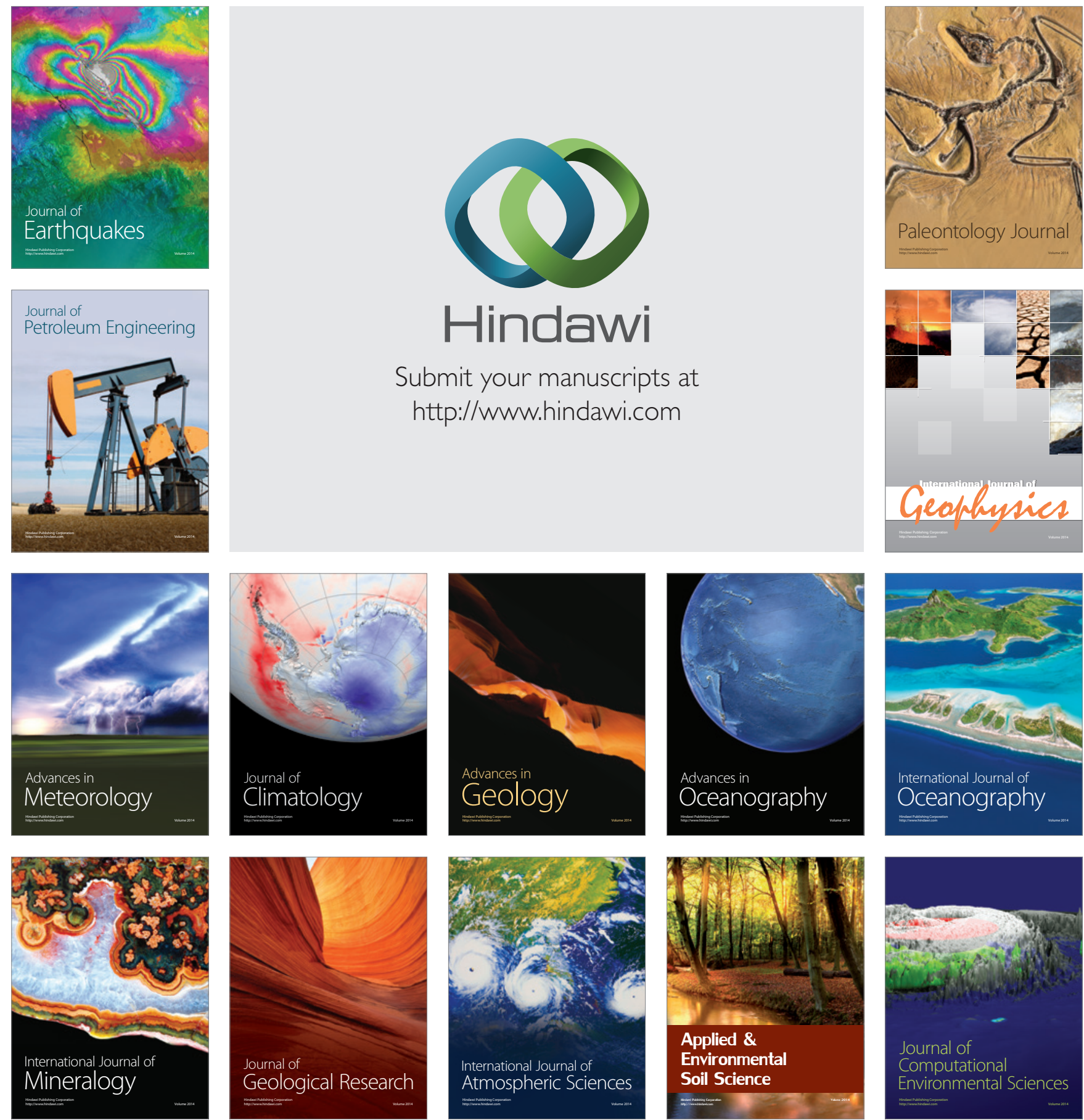